\title{
Sosialisasi Deteksi Dini Kanker Serviks dan Kanker Payudara pada Komunitas Umat Basis
}

\author{
Maria Helena Carolinda Dua Mea \\ Universitas Flores \\ helenaduamea@gmail.com
}

\begin{abstract}
Abstrak
Sosialisasi deteksi dini Kanker Serviks dan Kanker Payudara dilakukan pada Komunitas Umat Basis "Reinha Rosari” pada Paroki St. Josef Freinademetz Mautapaga Kota Ende. KUB merupakan elemen masyarakat yang paling aktif, juga merupakan obyek yang mudah dijangkau. Kegiatan sosialisasi diawali dengan pembekalan narasumber sosialisasi oleh Seksi Kesehatan Dewan Pastoral Paroki (DPP) St. Josef Freinademetz Mautapaga pada Jumat, 13 Desember 2019. Kegiatan Sosialisasi pada Komunitas Umat Basis diadakan pada hari Jumat, 31 Januari 2020 dengan mengadakan survei sederhana tentang seberapa besar pengetahuan peserta sosialisasi terhadap kanker serviks dan payudara, dilanjutkan dengan pemaparan materi sosialisasi, lalu diadakan sesi tanya jawab dan berbagi pengalaman, kemudian pembagian leaflet dan stiker waspada kanker serviks dan kanker payudara. Peralatan dan perlengkapan yang digunakan dalam kegiatan ini adalah microphone, fotokopi materi sosialisasi, leaflet deteksi dini kanker, serta stiker waspada kanker serviks dan payudara. Di masa yang akan datang diharapkan kegiatan sosialisasi ini dapat terus dilaksanakan dalam skala yang lebih luas seperti di tingkat RT, RW maupun Kelurahan dan Kecamatan, dengan melibatkan pihak medis dan pihak terkait serta elemen masyarakat lainnya, serta kaum pria dapat lebih terlibat dan berperan aktif dalam kegiatan sosialisasi ini.
\end{abstract}

Kata Kunci: sosialisasi, deteksi dini, kanker serviks, kanker payudara, Ende

\section{Socialization of Early Detection of Cervical Cancer and Breast Cancer in Community Basis}

\begin{abstract}
The socialization of early detection of cervical cancer and breast cancer was carried out at the "Reinha Rosari" Community Base at Sts Parish. Josef Freinademetz Mautapaga City of Ende. KUB is the most active element of society, as well as objects that are easily accessible. The socialization activity was started with a briefing of resource persons for the socialization by the Health Section of the Parish Pastoral Council (DPP) St. Josef Freinademetz Mautapaga on Friday, 13 December 2019. Socialization activities for the Basic Community were held on Friday, 31 January 2020 by conducting a simple survey on how much knowledge the participants of the socialization had on cervical and breast cancer, followed by the presentation of the socialization material, then held a session questions and answers and sharing of experiences, then distributing leaflets and stickers on cervical and breast cancer alert. The equipment and equipment used in this activity are microphones, photocopies of socialization materials, leaflets for early cancer detection, and cervical and breast cancer alert stickers. In the future, it is hoped that this socialization activity can continue to be carried out on a broader scale such as at the $R T, R W$ and Kelurahan and Subdistrict levels, by involving medical and related parties as well as other elements of society, and men can be more involved and play an active role in this outreach activity.
\end{abstract}

Keywords: socialization, early detection, cervical cancer, breast cancer, Ende

\section{PENDAHULUAN}

Kesehatan merupakan hal yang penting dalam kehidupan setiap individu. Dengan kesehatan maka seseorang dapat menjalankan segala bentuk aktivitas dan menghasilkan karya dalam masyarakat tanpa terganggu oleh rasa sakit. Masyarakat yang sehat akan menunjang pembangunan suatu bangsa dan negara, tetapi tidak dapat dipungkiri bahwa penyakit dan berbagai jenis penyakit, baik generative (diwariskan) atau degenerative (disebabkan oleh gaya hidup) saat ini banyak bermunculan di tengah-tengah masyarakat. 
Beberapa penyakit itu di antaranya adalah kanker serviks (kanker leher rahim) dan kanker payudara yang mengancam kaum perempuan.

Kanker serviks adalah kanker dengan jumlah paling banyak ke dua yang diderita wanita di Indonesia, setelah kanker payudara, dari angka kejadian atau kasusnya serta angka kematiannya. Setiap tahun, ada sekitar 14.000 wanita didiagnosis menderita kanker serviks dan lebih dari 7.000 orang meninggal dunia akibat kanker. Hal ini berarti dalam setiap satu jam, terdapat satu orang wanita yang meninggal dunia karena kanker serviks atau kanker rahim, dengan prevalensi dalam lima tahun sekitar 64,9\% (Kompas.com, 2017).

Kanker serviks biasanya disebabkan oleh pernikahan dini dan memiliki anak sebelum usia 20 tahun, perilaku seksual yang bebas dan gaya hidup yang tidak sehat (seperti merokok dan kelelahan) (Kusumawati et al., 2016), (Karisma, 2017). Sedangkan kanker payudara biasanya disebabkan oleh gaya hidup yang tidak sehat, obesitas, dan tidak pernah menyusui (Yulianti et al., 2016), (Lubis, 2017), (Irawan, 2018). Akan tetapi setiap wanita dapat mencegahnya dengan melakukan skrining atau pemeriksaan mandiri (Angrainy, 2017). Sayangnya, karena kurangnya pengetahuan, dan pemahaman tentang kanker ini menjadikan masyarakat kurang paham bahwa kanker serviks dan payudara bisa dicegah dan diobati sejak dini (Aeni \& Yuhandini, 2018). Saat ini penyakit Kanker Serviks dan Payudara merupakan penyumbang tertinggi angka kematian kaum perempuan di antara jenis kanker yang ada (Kemkes.go.id, 2019). Kanker serviks sebenarnya bisa dicegah dengan melakukan perilaku seksual yang baik. Selain itu, pemberian vaksin yang sebelumnya harus disesuaikan dengan hasil pemeriksaan pasien, atau juga bisa dengan vaksinasi Human papilloma virus (HPV).

Karena pengetahuan masyarakat terhadap kanker dan upaya pencegahan dan penanggulangannya masih sangat rendah maka penyakit Kanker Serviks dan Payudara masih menempati urutan teratas penyumbang kematian kaum perempuan (Triharini et al., 2019; Kusumawati et al., 2016; Lubis, 2017). Untuk itu diperlukan suatu gerakan yang menyeluruh dan merata guna meningkatkan pemahaman mengenai kanker dan salah satunya melalui kegiatan-kegiatan seperti sosialisasi. Ketidaktahuan masyarakat khususnya kaum perempuan Indonesia termasuk di Kabupaten Ende pada bahaya Kanker Payudara dan Serviks perlu disikapi dengan peningkatan upaya promotif-preventif, antara lain dengan melaksanakan sosialisasi, advokasi dan edukasi di berbagai elemen masyarakat (Endekab.go.id, 2017).

Kaum perempuan di Provinsi Nusa Tenggara Timur dan Kabupaten Ende khususnya masih sangat awam dalam pemahaman mengenai pentingnya deteksi dini kanker leher rahim, sehingga sebagian besar kasus ditemukan terlambat dan Ketika pada akhirnya datang berobat ke rumah sakit, penyakit tersebut sudah berada pada stadium akhir. Di Kabupaten Ende target pemeriksaan IVA masih belum tercapai. Data distribusi penderita kanker berdasarkan organ menurut pemeriksaan histopatologi di instalasi patologi anatomi RSUD WZ Johanes Kupang-NTT menunjukkan bahwa penderita kanker terbanyak adalah kanker serviks dengan jumlah 32 jiwa. Selanjutnya, kanker ovarium 31 jiwa, kanker payudara 27 jiwa, rongga mulut 16 jiwa, thyroid dan saluran cerna 14 jiwa, serta kelenjar getah bening 12 jiwa (Kompas.com, 2020) Dalam pemeriksaan lanjutan kepada para pasien, hampir sebagian penyakit kanker ditemukan pada kondisi yang sudah masuk stadium lanjut.

Deteksi dini kanker serviks lewat pemeriksaan IVA (inspeksi visual asam asetat) dianggap dapat membantu menyelamatkan banyak perempuan karena relatif 
Vol. 2, No. 1, March, 2021, pp. $40-49$

e-ISSN: 2722-2004

Socialization of Early

Detection of Cervical

Cancer and Breast Cancer in Community Basis

mudah dilakukan dan hasilnya lebih cepat diperoleh dibandingkan metode papsmear (Nur'aini \& Ulina, 2020; Kusumawati et al., 2016). Pemeriksaan IVA dilakukan dengan meneteskan asam asetat (asam cuka) pada permukaan mulut rahim. Teknik ini dinilai terjangkau, mudah, hanya memerlukan alat sederhana, dan hasilnya bisa langsung didapatkan.

Salah satu elemen masyarakat yang ada di Kabupaten Ende yaitu Komunitas Umat Basis (KUB), yang merupakan bagian dari komunitas keagamaan umat Katolik yang resmi. KUB ini dibentuk selain untuk menyatukan umat dalam aktivitas kerohanian di dalam wadah yang resmi yang ditunjuk oleh pimpinan Gereja Katolik, juga untuk mempermudah pemerintah dan gereja dalam mensosialisasikan program kerja Gereja dan Pemerintah Daerah. KUB memegang peranan penting dalam elemen masyarakat Kabupaten Ende, karena mayoritas masyarakat Kabupaten Ende menganut agama Katolik. Sebanyak 50\% aktivitas kerohanian masyarakat Ende yang beragama Katolik dihabiskan di dalam komunitas ini. Di Kota Ende yang merupakan ibukota Kabupaten Ende, terdapat 6 Paroki Gereja Katolik, yang terdiri dari ratusan Komunitas Umat Basis di tiaptiap Paroki yang masing-masingnya memiliki nama sesuai dengan Surat Keputusan Pastor Paroki yang dinaungi KUB tersebut.

Berdasarkan permasalahan yang sudah dipaparkan di atas, maka penulis memberikan sosialisasi deteksi dini Kanker Serviks dan Kanker Payudara pada Komunitas Umat Basis "Reinha Rosari" pada Paroki St. Josef Freinademetz Mautapaga Kota Ende. Obyek kegiatan pengabdian masyarakat ini dipilih pada umat KUB selain karena KUB merupakan elemen masyarakat yang paling aktif, juga merupakan obyek yang mudah dijangkau oleh penulis. Dengan pemberian sosialisasi ini, masyarakat di tingkat komunitas Umat Basis baik kaum pria (yang sudah menikah) maupun kaum perempuan serta para remaja putri mendapatkan pengetahuan mengenai kanker serviks dan kanker payudara. Dengan pengetahuan yang diperoleh itu, mereka juga dapat menjadi penyebar informasi yang benar kepada anggota masyarakat yang lain. Kegiatan sosialisasi ini juga dapat membantu pemerintah daerah dalam mensosialisasikan deteksi dini kanker serviks dan kanker payudara dan pada akhirnya berkontribusi pada pengembangan sumber daya manusia yang sehat dan berkualitas yang dapat mendukung pembangunan ekonomi nasional.

\section{METODE PELAKSANAAN}

Sosialisasi deteksi dini kanker serviks dan kanker payudara diadakan pada masa sebelum pandemi Covid-19 yaitu pada Jumat, 31 Januari 2020 pukul 18.0020.00. Waktu tersebut dipilih karena Jumat adalah hari menjelang akhir pekan sehingga tidak mengganggu pekerjaan utama masyarakat dan waktu yang dipilih adalah sore hari. Sasaran kegiatan sosialisasi adalah kaum perempuan baik perempuan dewasa maupun remaja putri, serta kaum lelaki yang sudah berkeluarga. Jumlah peserta sosialisasi adalah 40 orang, terdiri dari 30 Kepala keluarga beserta istri dan 10 orang remaja putri.

Kegiatan sosialisasi diawali dengan pembekalan narasumber sosialisasi oleh Seksi Kesehatan Dewan Pastoral Paroki (DPP) St. Josef Freinademetz Mautapaga di hari Jumat, 13 Desember 2019. Materi yang diberikan dalam pembekalan adalah Pengertian kanker serviks, penyebab, dan pencegahannya, pemeriksaan IVA, 
pengertian kanker payudara, pencegahan serta pengobatan kanker payudara. Di akhir sosialisasi, para calon narasumber dibagikan handout, leaflet, dan sticker yang akan dibagikan kepada peserta sosialisasi di Komunitas masing-masing.

Kegiatan Sosialisasi pada Komunitas Umat Basis diadakan pada hari Jumat, 31 Januari 2020 dengan mengadakan survei sederhana tentang seberapa besar pengetahuan peserta sosialisasi terhadap kanker serviks dan payudara, dilanjutkan dengan pemaparan materi sosialisasi, lalu diadakan sesi tanya jawab dan berbagi pengalaman, kemudian pembagian leaflet dan stiker waspada kanker serviks dan kanker payudara. Peralatan dan perlengkapan yang digunakan dalam kegiatan ini adalah microphone, fotokopi materi sosialisasi, leaflet deteksi dini kanker, serta stiker waspada kanker serviks dan payudara.

\section{HASIL DAN PEMBAHASAN}

Survei sederhana diadakan pada awal kegiatan sosialisasi untuk mengetahui seberapa besar pengetahuan peserta sosialisasi terhadap kanker serviks dan kanker payudara. Hasil survei menunjukkan bahwa hanya $12.5 \%$ peserta sosialisasi yang pernah mendengar atau membaca tentang kanker serviks dan payudara. Sebagian besar peserta tidak pernah mendengar atau membaca informasi mengenai kanker serviks dan payudara, gejala maupun pencegahan serta pengobatannya. Survei ini diadakan agar penulis dapat menyampaikan materi sosialisasi secara terarah dan tepat pada sasaran. Hasil survei ditunjukkan pada grafik berikut ini:

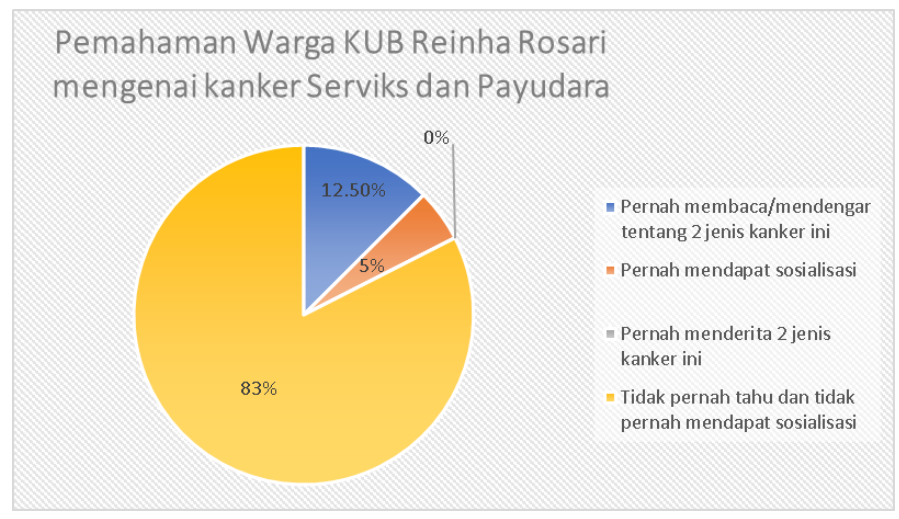

Gambar 1. Grafik hasil survei pemahaman warga KUB Reinha Rosari tentang kanker payudara dan kanker serviks

Setelah dilakukan survei kemudian dilanjutkan dengan sosialisasi tentang kanker serviks dan payudara yaitu pada topik-topik mengenai:

1) Jenis-jenis kanker yang mengancam perempuan

2) Pengertian kanker serviks

3) Penyebab kanker serviks

4) Pencegahan kanker serviks

5) Pemeriksaan IVA

6) Pengertian kanker payudara

7) Penyebab kanker payudara

8) Pencegahan dan pengobatan kanker payudara 
Vol. 2, No. 1, March, 2021, pp. $40-49$

e-ISSN: 2722-2004

Socialization of Early

Detection of

Cervical

Cancer and Breast Cancer in Community Basis

9) Peran suami dan ayah dalam pencegahan dan pengobatan kanker serviks dan payudara.

Topik yang diberikan pada kegiatan sosialisasi tersebut berpedoman pada materi pembekalan dan juga mengadaptasi karya pengabdian serupa yang telah diadakan oleh (Dharmesti Wijaya et al., 2019) dengan sasaran pada Komunitas Pedagang Canang di Pasar Kreneng Denpasar Utara pada 2019, dan mengadaptasi topik sosialisasi oleh (Triharini et al., 2019). Sosialisasi dilakukan dengan terlebih dahulu membagikan fotokopi materi sosialisasi, kemudian pemaparan materi sosialisasi oleh penulis sendiri selaku narasumber utama.

Sesi tanya jawab kemudian dilakukan dengan tidak membatasi jumlah penanya. Sesi ini digabungkan dengan sharing pengalaman warga yang melihat dan mengalami anggota keluarga, sahabat maupun kenalan yang pernah mengalami kanker serviks maupun payudara. Pada sesi terakhir, diadakan survei untuk mengetahui tingkat pemahaman peserta sosialisasi setelah kegiatan, lalu dibagikan leaflet dan stiker waspada kanker serviks dan payudara untuk selalu mengingatkan warga masyarakat untuk memiliki pola hidup sehat dan kesadaran dalam melakukan deteksi dini kanker serviks dan payudara.

Di akhir sesi sosialisasi penulis kembali mengadakan survei untuk mengetahui tingkat pemahaman peserta setelah mendapatkan sosialisasi deteksi dini kanker serviks dan kanker payudara. Hasil survei disajikan dalam grafik berikut:

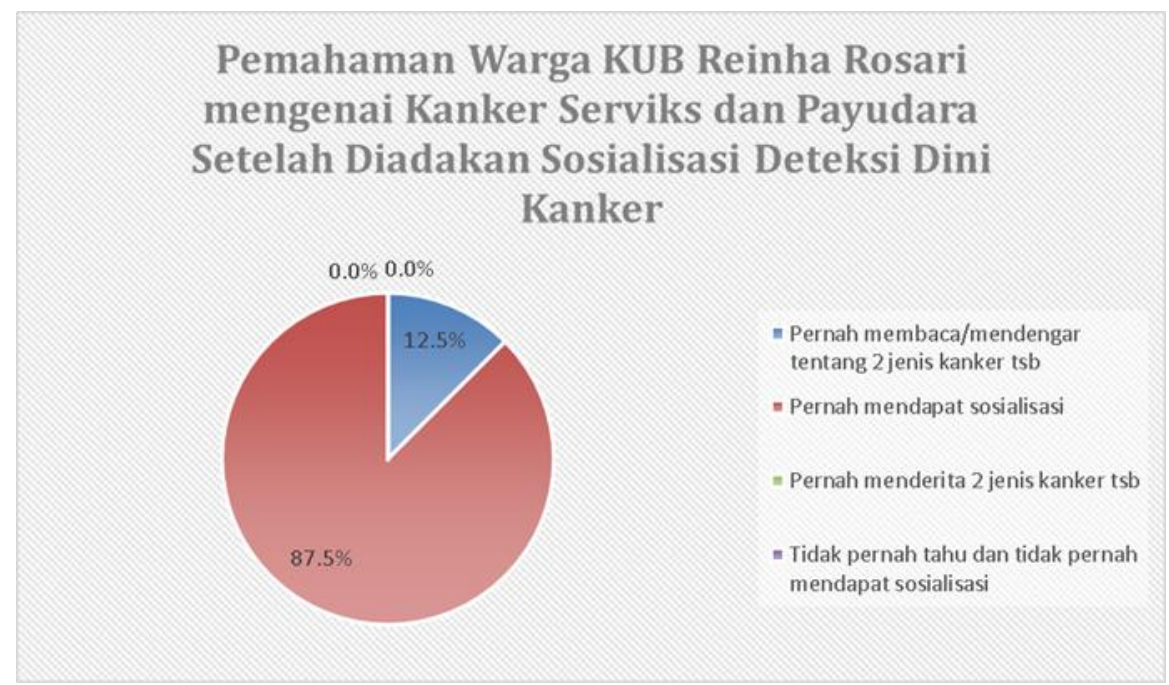

Gambar 2. Grafik survei tingkat pemahaman peserta setelah sosialisasi

Sosialisasi sebagai bagian promosi kesehatan merupakan upaya untuk meningkatkan pengetahuan dan perilaku perempuan serta masyarakat pada umumnya sehingga masyarakat mampu untuk memelihara dan meningkatkan kesehatan (Triharini et al., 2019). Setelah diberikan sosialisasi tentang deteksi dini kanker serviks dan kanker payudara maka diperoleh peningkatan pengetahuan dari warga dan kaum perempuan pada Komunitas Umat Basis Reinha Rosari Ende. Hal ini sesuai dengan hasil penelitian dari (Aeni \& Yuhandini, 2018), (Angrainy, 2017), (Irawan, 2018), (Karisma, 2017), dan (Nur'aini \& Ulina, 2020) yang menunjukkan bahwa kegiatan promosi kesehatan (sosialisasi dan penyuluhan) 
mampu meningkatkan pengetahuan kaum perempuan dan masyarakat tentang kanker serviks dan kanker payudara untuk mendukung peningkatan perilaku deteksi dini dengan pemeriksaan IVA dan SADARI. Setelah diberikan sosialisasi didapatkan peningkatan sikap dari kaum perempuan di KUB Reinha Rosari sebanyak 87.5\% untuk melakukan deteksi kanker dengan metode IVA. Hal ini sesuai dengan penelitian dari (Nur'aini \& Ulina, 2020) bahwa peningkatan pengetahuan akan diikuti dengan peningkatan sikap positif.

Dari sesi diskusi dan tanya jawab didapatkan masih terdapat perempuan yang memiliki sikap enggan dalam keinginan untuk melakukan pemeriksaan IVA karena tidak ingin mengetahui hasilnya jika tidak baik atau terdeteksi kanker, walaupun telah memiliki pengetahuan yang cukup tentang kanker serviks. Diharapkan dengan adanya kegiatan sosialisasi ini adalah semakin meningkatnya perilaku deteksi dini kanker serviks dengan metode IVA dan kanker payudara dengan metode SADARI. Karena penelitian (Nur'aini \& Ulina, 2020) dan (Kusumawati et al., 2016) menunjukkan bahwa IVA test memiliki beberapa keunggulan yaitu cepat, aman, akurat dan terjangkau.

Dalam upaya peningkatan kesadaran perempuan akan kesehatannya, dibutuhkan dukungan dari keluarga, masyarakat, maupun tenaga Kesehatan, karena hasil penelitian (Lumowa et al., 2015) dan (Pakkan, 2017) menunjukkan bahwa motivasi perempuan untuk melakukan deteksi dini kanker sangat ditentukan oleh lingkungan keluarga dan masyarakat, selain tenaga kesehatan yaitu para bidan (Soimah, 2019).

Berikut beberapa dokumentasi kegiatan sosialisasi kanker serviks dan payudara pada Komunitas Umat Basis "Reinha Rosari" dari kegiatan pembekalan narasumber sosialisasi oleh Seksi Kesehatan Dewan Pastoral Paroki St. Josef Freinademetz Mautapaga hingga kegiatan sosialisasi pada Komunitas Umat Basis "Reinha Rosari":

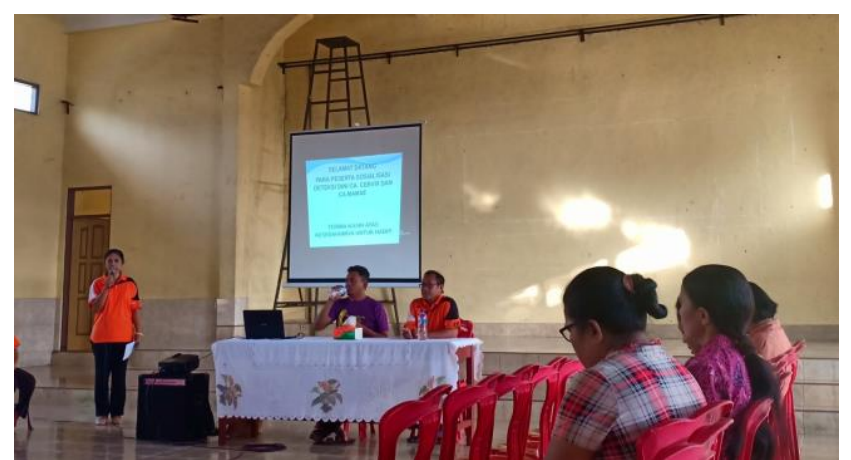

Gambar 3. Pembukaan pembekalan narasumber sosialisasi kanker serviks dan kanker payudara 
KANGMAS: Karya Ilmiah Pengabdian Masyarakat, Vol. 2 No. 1, March 2021 - 46

http://journal.neolectura.com/index.php/kangmas

Vol. 2, No. 1, March, 2021, pp. $40-49$

e-ISSN: 2722-2004

\section{Socialization of Early \\ Detection of \\ Cervical \\ Cancer and Breast Cancer in Community Basis}

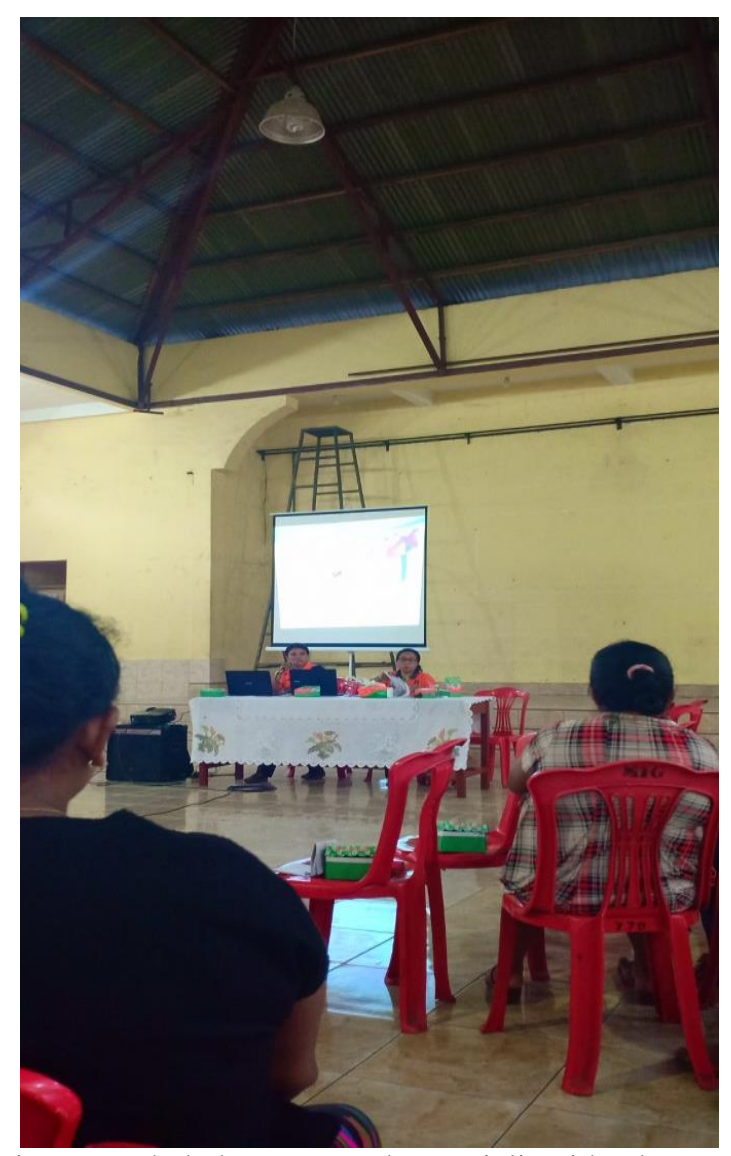

Gambar 4. Kegiatan pembekalan narasumber sosialisasi kanker serviks dan kanker payudara oleh Seksi Kesehatan DPP St. Josef Freinademetz Mautapaga

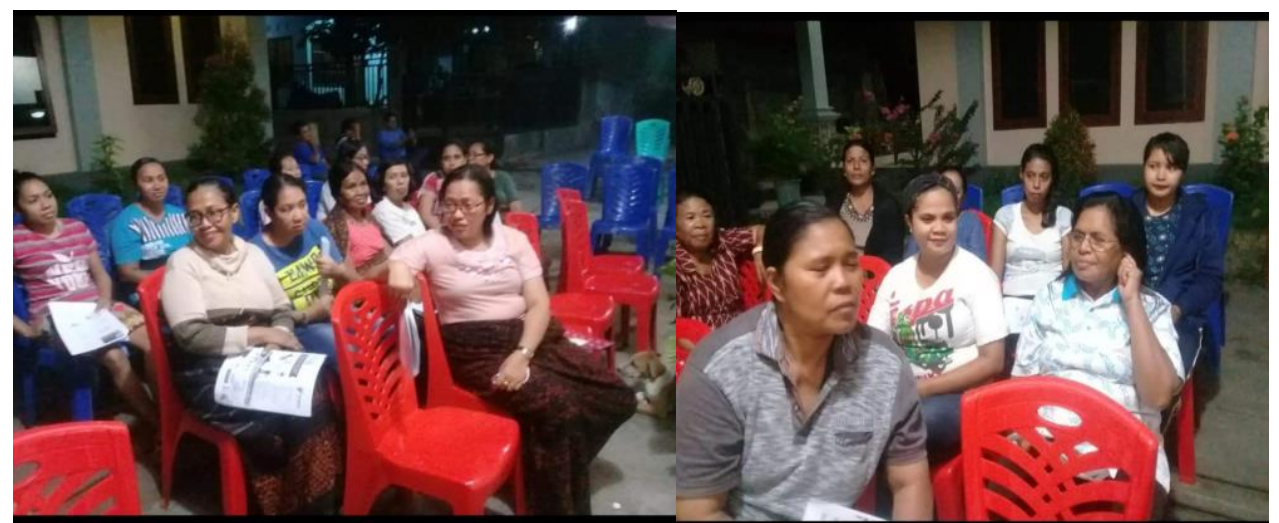

Gambar 5. Peserta sosialisasi deteksi dini kanker serviks dan payudara di KUB Reinha Rosari 
KANGMAS: Karya Ilmiah Pengabdian Masyarakat, Vol. 2 No. 1, March 2021 - 47 http://journal.neolectura.com/index.php/kangmas

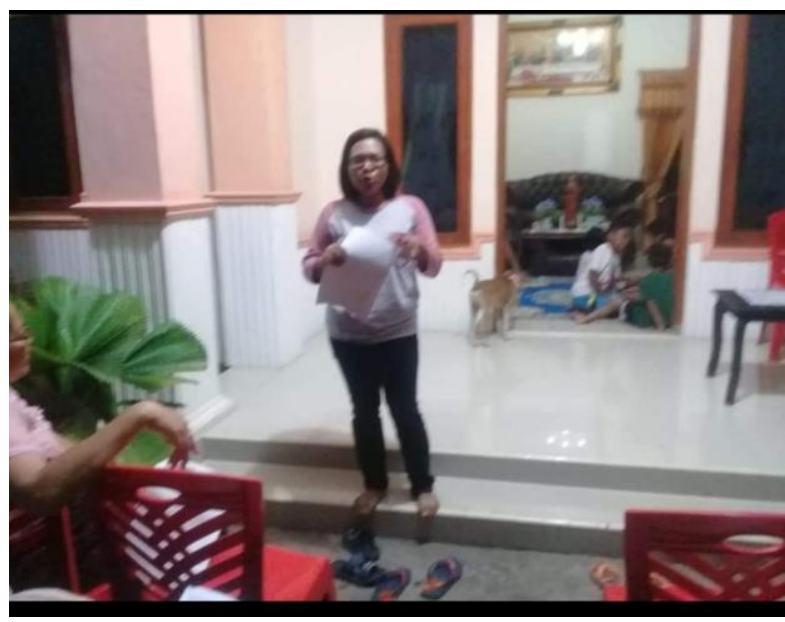

Gambar 6. Penulis selaku narasumber
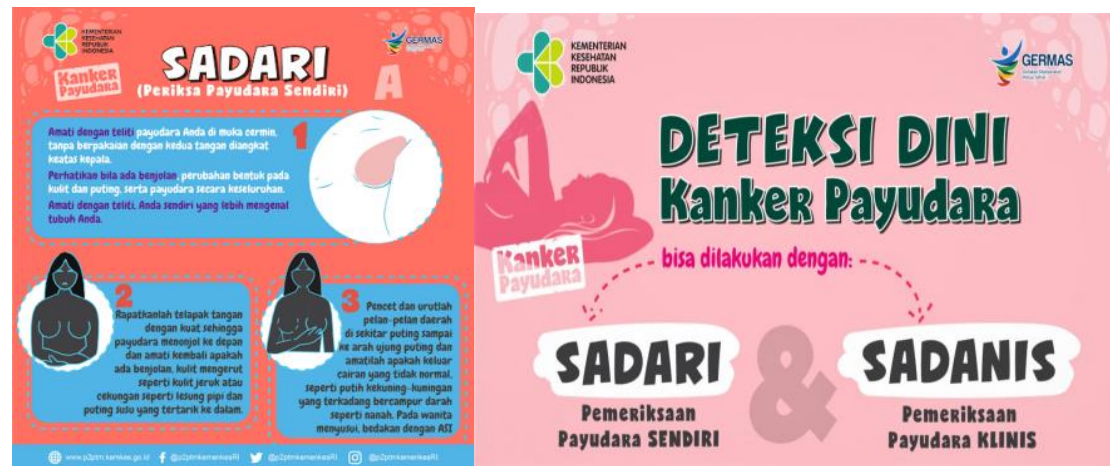

Gambar 7. Leaflet dan stiker deteksi dini kanker payudara

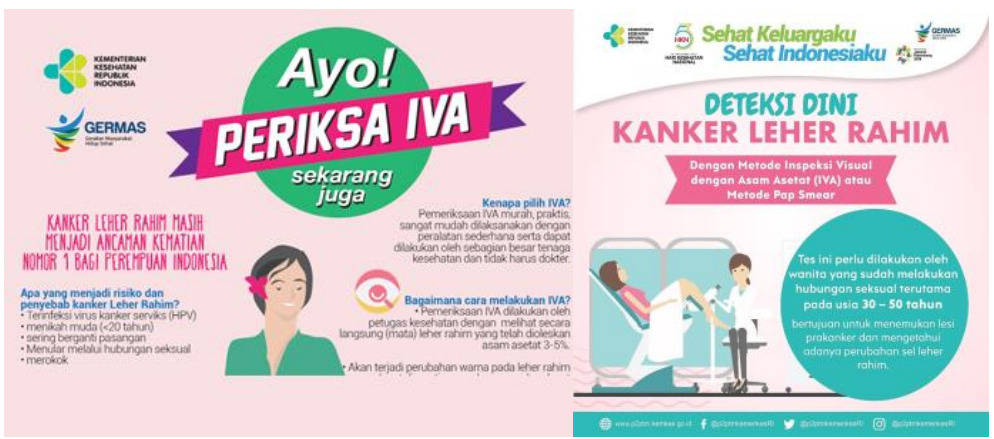

Gambar 8. Leaflet dan stiker deteksi dini kanker serviks

\section{SIMPULAN}

Setelah diadakan sosialisasi maka diperoleh sebanyak $88 \%$ warga masyarakat yang telah memiliki pengetahuan yang cukup tentang kanker serviks dan payudara yang dapat dibagikan kepada anggota keluarga dan masyarakat lainnya yang membutuhkan informasi tersebut. Di masa yang akan datang diharapkan kegiatan sosialisasi ini dapat terus dilaksanakan dalam skala yang lebih luas seperti di tingkat RT, RW maupun Kelurahan dan Kecamatan, dengan melibatkan pihak medis dan pihak terkait serta elemen masyarakat lainnya, serta kaum pria dapat lebih terlibat dan berperan aktif dalam kegiatan sosialisasi ini. 
Vol. 2, No. 1, March, 2021, pp. $40-49$

e-ISSN: 2722-2004

Socialization of Early

Detection of

Cervical

Cancer and Breast Cancer in Community Basis

\section{DAFTAR PUSTAKA}

Aeni, N., \& Yuhandini, D. S. (2018). Pengaruh Pendidikan Kesehatan Dengan Media Video Dan Metode Demonstrasi Terhadap Pengetahuan SADARI. Care : Jurnal Ilmiah Ilmu Kesehatan. https://doi.org/10.33366/cr.v6i2.929

Angrainy, R. (2017). Hubungan pengetahuan, sikap tentang sadari dalam mendeteksi dini kanker payudara pada remaja. Jurnal Endurance. https://doi.org/10.22216/jen.v2i2.1766

Dharmesti Wijaya, M., Indraningrat, A., Sri Masyeni, D., \& Santosa, A. (2019). Penyuluhan deteksi dini kanker serviks dan kanker payudara pada Komunitas Pedagang Canang di Pasar Kreneng Denpasar Utara. Buletin Udayana Mengabdi. https://doi.org/10.24843/bum.2019.v18.i04.p08

Irawan, E. (2018). Faktor-faktor pelaksanaan sadari/breast self examination (BSE) kanker payudara (literature review). Jurnal Keperawatan BSI. https://doi.org/10.31311/.V6I1.3690

Karisma, L. S. (2017). Pengaruh Promosi Kesehatan Terhadap Pengetahuan Tentang Kanker Serviks dan Partisipasi Wanita dalam Deteksi Dini Kanker Serviks (di Mojongsongo RW 22 Surakarta). Pengaruh Promosi Kesehatan Terhadap Pengetahuan Tentang Kanker Serviks Dan Partisipasi Wanita Dalam Deteksi Dini Kanker Serviks.

Kusumawati, Y., Nugrahaningtyas, R. W., \& Rahmawati, E. N. (2016). Pengetahuan, Deteksi Dini dan Vaksinasi HPV sebagai Faktor Pencegah Kanker Serviks di Kabupaten Sukoharjo. Jurnal Kesehatan Masyarakat. https://doi.org/10.15294/kemas.v11i2.4208

Lubis, U. L. (2017). Pengetahuan Remaja Putri Tentang Pemeriksaan Payudara Sendiri (SADARI) dengan Perilaku Sadari. Jurnal Aisyah : Jurnal Ilmu Kesehatan. https://doi.org/10.30604/jika.v2i1.36

Lumowa, M., Mandang, J., \& Lumy, F. (2015). Pengaruh Promosi Kesehatan Tentang Kanker Serviks Terhadap Peningkatan Pengetahuan Ibu. Jurnal Ilmiah Bidan.

Nur'aini, \& Ulina, M. (2020). Pengaruh faktor internal dan eksternal terhadap tindakan wanita usia subur dalam deteksi dini kanker serviks melalui pemeriksaan test IVA. Jurnal Kesehatan Dr. Soebandi.

Pakkan, R. (2017). Faktor-faktor yang berhubungan dengan motivasi ibu melakukan pemeriksaan metode Inspeksi Visual Asam Asetat (IVA) di Kelurahan Lepo-Lepo Kota Kendari. Jurnal Ilmiah Bidan.

Soimah, N. (2019). Analisis Yuridis Peran Bidan Puskesmas Terhadap Upaya Promotif Deteksi Dini Kanker Serviks. Jurnal SMART Kebidanan. https://doi.org/10.34310/sjkb.v6i2.294

Triharini, M., Yunitasari, E., Armini, N. A., Kusumaningrum, T., Pradanie, R., \& Nastiti, A. A. (2019). Pemberdayaan perempuan melakukan deteksi dini kanker serviks melalui pelatihan metode reproductive organ self examination (ROSE) sebagai upaya deteksi dini penyakit kanker serviks. 
KANGMAS: Karya Ilmiah Pengabdian Masyarakat, Vol. 2 No. 1, March 2021 - 49

http://journal.neolectura.com/index.php/kangmas

Jurnal Pengabdian Masyarakat Dalam Kesehatan. https://doi.org/10.20473/jpmk.v1i1.12326

Yulianti, I., Santoso, H., \& Sutinigsih, D. (2016). Faktor-faktor risiko kanker payudara (studi kasus pada Rumah Sakit Ken Saras Semarang). Jurnal Kesehatan Masyarakat Universitas Diponegoro.

https://sains.kompas.com/read/2017/10/26/131137423/penderita-kanker-di-nttmeningkat-tiap-tahun-kanker-serviks-terbanyak

https://sains.kompas.com/read/2020/02/04/190300123/kanker-serviks-penyebabkematian-nomor-2-wanita-indonesia-kenapa?page=all

https://www.alodokter.com/pemeriksaan-iva-untuk-deteksi-dini-kanker-serviks

http://p2p.kemkes.go.id/penyakit-kanker-di-indonesia-berada-pada-urutan-8-di-asiatenggara-dan-urutan-23-di-asia/

http://p2ptm.kemkes.go.id/post/sosialisasi-deteksi-dini-kanker-leher-rahim-denganmetode-iva-di-wilayah-puskesmas-roga-kabupaten-ende-ntt

http://p2ptm.kemkes.go.id/kegiatan-p2ptm/nusa-tenggara-timur/screening-iva-testdi-puskesmas-onekore-kabupaten-ende-provinsi-ntt

http://portal.endekab.go.id/component/content/article/40-berita/2375-penyakitkanker-serviks-dan-payudara-penyumbang-tertinggi-angka-kematian.html

http://portal.endekab.go.id/component/content/article/40-berita/2309-kankerserviks-dan-payudara-tertinggi-penyebab-kematian.html 